\title{
Protecting California Oil Fields from Damage by Infiltrating Water
}

\author{
BY R. P. MCLAUGHLIN, * gAN FRANCISCO, CAL.
}

(San Francisco Meeting, September, 1915)

IN most branches of the mining industry it is a well-recognized fact that care must be taken to protect the mineral deposit from undue physical injury. It is comparatively easy to grasp this idea when the mineral is a solid and the lives of workmen depend directly upon the care with which it is removed from its natural position, but when the product is a liquid drawn up from pools several thousand feet beneath the surface of the ground through openings only a few inches in diameter, it requires some imagination to picture underground conditions and the changes which must often occur. The development of the petroleum deposits of California has been attended by numerous accidents, the results of which are readily noticed at the top of the wells and in the profit and loss accounts of the operators. Determination of the cause of these accidents has been the subject of considerable study, which naturally has fallen upon men familiar with technical methods.

The greatest damage to the oil deposits of California has resulted from water finding its way into the oil-bearing sands, and it is the purpose of this paper to set forth briefly this phase of the oil industry. Much of the material here presented has previously appeared in publications issued by the California State Mining Bureau, which, under the direction of State Mineralogist Fleteher McN. Hamilton, has investigated the subject and taken steps toward improvement of conditions. The writer, having been in charge of this branch of the Bureau work, has gained considerable knowledge of existing conditions.

Generally speaking, the oil-bearing formations of California are soft, unconsolidated sand beds, separated by clay strata, which are also soft. Some of the sand beds carry water instead of oil. All of the beds are more or less separated, probably being of lenticular shape. Very few of the beds in the oil fields lie flat or undisturbed over any great area. Folding and tilting are common, and faulting also occurs in some of the fields. The accumulation of oil is not confined to any single structural feature, such as the anticline, but occurs in many other structural features. Water-bearing strata occur in practically every oil field in the State. Complete data are not at hand for a comparison of the damage

* State Oil and Gas Supervisor.

VOL. LII. -15 
done in the various fields. These water sands are sometimes above, below, and between the oil sands. When water and oil sands are both penetrated by a well, the water enters the oil sand. The water frequently forces the oil back into the sand so that pumping produces nothing but water. The water not only damages the well which it first enters, but affects neighboring wells, causing their product to become partly or entirely water. The probability of such damage is usually foreseen. The method of preventing damage from this source is to insert screw pipe (or casing) into the well. It serves as the lining or wall of the well, and if carried through and below the water sand and firmly landed in some sort of impervious stratum, such as clay, it prevents the water from leaking down into the well. Sometimes it is necessary to pump cement in behind the casing in order to seal thoroughly the passages down which the water might otherwise run. Several such lines (or strings) of casing are sometimes placed inside the first one until together they resemble a telescope with the small end at the bottom of the well, in the oil sand.

The protection of a well from water intrusion comprises two operations: First, determining where the casing should be landed; and, second, the actual work of placing the casing in the well in a workmanlike manner. These operations are interdependent, and either is useless without the other.

Some idea of the financial loss of the oil operator, when water is not controlled, may be had from the following instances:

In the Coalinga field on a certain property is a well about $2,700 \mathrm{ft}$. deep. It was drilled three or four years ago at a cost of about $\$ 30,000$. Initial production was over $200 \mathrm{bbl}$. of oil per day and the total production about $100,000 \mathrm{bbl}$. of oil, giving a profit of possibly $\$ 10,000$ over regular operating expenses, but not including the cost of the well. About two years ago water stopped this production entirely. The owners are financially unable to repair the well at present, and each day adds to the damage being done to surrounding property.

In a portion of the Midway-Sunset field there are two known oil sands, both productive. There are water-bearing sands above the upper oil sand and also between the two oil sands. When a well is drilled into the lower sand two extra strings of casing (about 2,000 ft. of 8-in. and 2,500 ft. of 6-in.) should be inserted to keep the water out of the upper sand. The expense for extra casing and labor may amount to $\$ 10,000$ per well. Some operators have neglected or refused to protect their wells in this manner, which has resulted in serious damage to the wells of other operators which depend upon the upper sand, because they are of too small diameter to allow deeper drilling.

An approximate idea of the ultimate loss that will ensue, unless the top sand is protected, may be gained from the following figures: A 
single well, at present producing, has during three and a half years produced almost $300,000 \mathrm{bbl}$. of oil. Other wells, though not so large, should produce for a much longer time than three and a half years, and $300,000 \mathrm{bbl}$. each is not an unreasonable estimate of their total production. The upper sand extends over about 400 acres, and at 5 acres per well should supply 80 wells, or a total of not less than $24,000,000 \mathrm{bbl}$, , or $\$ 12,000,000$.

A minor instance which came under notice is typical of much inefficient work that has been done. A superintendent, who had previously finished several wells satisfactorily with advice from a geologist, proceeded without such advice and drilled another well too far through the oil sand and encountered a strong flow of water. This "bottom water" was encountered within $2 \mathrm{ft}$. of where it had been expected by the geologist, from his study of logs of surrounding wells. Advice would have been to stop drilling about $15 \mathrm{ft}$. above the point to which it was carried. A contractor was engaged to cement the bottom of the hole after the flow of water had been checked by a "bridge." Even if the first cementing operation proved successful, the needless expense on this well probably amounted to about $\$ 500$. The chief aim of the geologist or engineer is to meet such circumstances in time to prevent trouble, rather than to aid in patching up improperly drilled wells, which procedure is, at best, apt to be troublesome and unsatisfactory.

It must be borne in mind, of course, that the natural oil reservoirs are exhaustible and as the oil is removed water is apt to take its place. Some operators are prone to assume that the presence of water in an oil well is perfectly natural and that infiltration could not have been avoided. It has been proved that this hypothesis is not always correct, for in many cases where water has appeared, the correction of faulty material or workmanship has caused the water to disappear.

There are at least three causes for water entering oil wells: (1) failure of casing, (2) faulty drilling operation, and, (3) natural replacement of oil by water as the oil is pumped out. There are also combinations and variations of these causes, modified and accelerated by movements of the ground itself.

The accompanying sketch (Fig. 1) of the bottom of four wells in the Coalinga field illustrates some of the underground conditions and the methods of recording and presenting the data. The wells were drilled in order as numbered. The strata are not bent or deformed in this particular locality. In each well the 10-in. casing was intended to shut off the water occurring above the oil sands, and in well No. 3 it was landed at a depth of 1,880 ft., in conformity with successful results at No. 1 and No. 2. However, the sand between $1,980 \mathrm{ft}$. and 2,016 ft. was found to contain some oil and considerable water, hence it was necessary to úse more casing to shut off this water. Since some experimenting was 


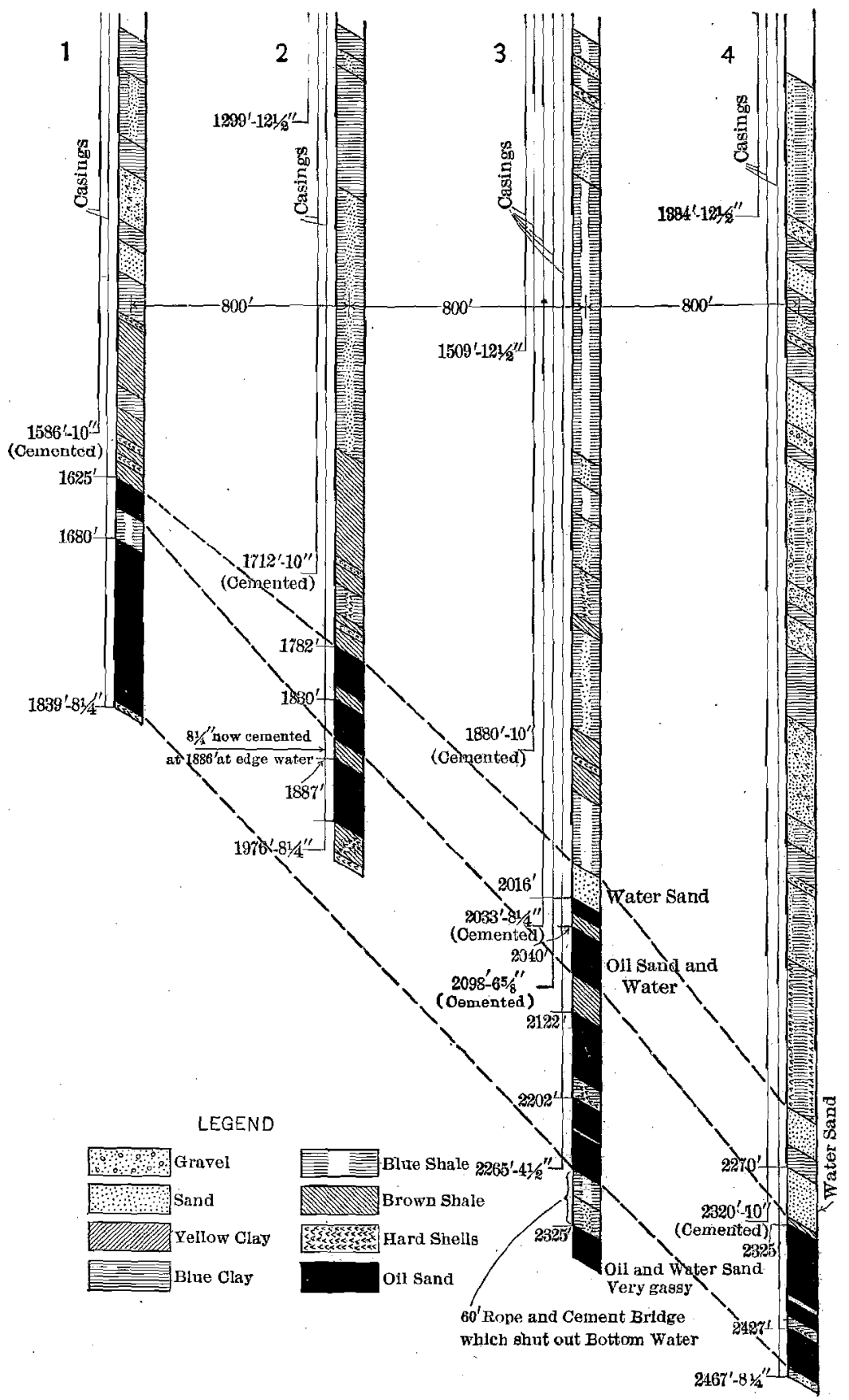

Fig. 1.-Crose-Section of Lower Part of Four Wells in the Coalinga Otl Finld, California. 
necessary, two strings, the $81 / 4$ in. at $2,033 \mathrm{ft}$. and the $65 / 8$ in. at $2,098 \mathrm{ft}$., were used. Had all conditions been known beforehand only one string would have been necessary, but when the $81 / 4$-in. casing was landed and the well drilled deeper more water was encountered and the $65 / 8$-in. casing had to be used. The final oil string of casing, $41 / 2$ in. in diameter, was carried to $2,351 \mathrm{ft}$. and upon testing, the well was found to produce mostly water, so the bottom was plugged (using waste, rope, iron lathe cuttings and cement) up to $2,265 \mathrm{ft}$. and the well again tested, when it was found to be free from water.

Since well No. 3 was one of the first wells in this locality to encounter water in the oil sands, where oil was expected, careful work was necessary on the next well drilled, to check the operations. This was done on neighboring wells, not shown on the drawing, and since similar results were found, when well No. 4 was drilled the top sands were shut off with the 10 -in. casing at $2,320 \mathrm{ft}$. The well was drilled to $2,467 \mathrm{ft}$. only, so as not to encounter the sand which contained water in well No. 3 between the 2,325 and 2,351 ft. levels.

After completion, all these wells produced clean oil for about a year, and then the No. 2 began to show a little water, and about three months later showed about 80 per cent. There were three possible sources of the water: From other wells through the oil sand, or from above the oil sand, or from the bottom sands penetrated. The drawing shows that the possibility of bottom water was slight. The possibility of water from above was tested by removing the $81 / 4$-in. "oil string," putting a "bridge" or plug in the open hole between the bottom of the 10-in. "water string" and the top of the oil sand. After bailing the well dry above the plug no water came in, proving that the "water string" was not leaking at any point and was effectively excluding upper water. Therefore the water in No. 2 was probably coming through the oil sand itself, and as the same sand showed both oil and water between 1,980 ft. and 2,095 ft. in No. 3 it was concluded that the water was rising along the dip. of that sand as the oil was removed. Such a movement is called the encroachment of "edge water:" The 81/4-in. casing was again put in and cemented at $1,886 \mathrm{ft}$. in the shale presumed to correspond to that found at 2,091 to $2,122 \mathrm{ft}$. in well No. 3, and 2,318 to $2,325 \mathrm{ft}$. in well No. 4 . After pumping the well for about 10 days, the oil was found to contain less than 1 per cent. water, proving that water had been coming through the upper sands, between 1,782 and 1,870 ft. After about four years the water has commenced to show in well No. 1 . This movement naturally follows the removal of oil and cannot be stopped, but the particular sand affected can be kept separated from other productive sands.

As in all other important industries involving the winning of some mineral product from the earth, a thorough plan should be mapped out, and followed or revised in the light of new developments. In other words, 
there should be a thorough geologic investigation. Some large operators realize this and have facilities for thorough geologic work at all times. Other large concerns give but little attention to the subject. Probably the oil industry is in this respect not so well managed as the metalmining industry. Small operators frequently feel that they cannot afford the expense of geologic work.

Several hundred oil companies are operating in California and in the past no concerted effort has been made by them to develop their lands systematically or to control the water trouble. Constant agitation of the subject has resulted in the passage of a law (Chapter 718, Statutes of 1915) framed by the State Mining Bureau, at the invitation and with the assistance of many oil operators. The law became effective Aug. 8, 1915. As it is along original lines; a brief outline may be interesting, together with some remarks upon the aims of its sponsors.

The law gives the State Mining Bureau supervision over this work, the expense being met by assessments upon the producers. The work is directed by an officer designated as State Oil and Gas Supervisor, who appoints four deputies; all of these officials must be either enginecrs or geologists. The Supervisor's headquarters will be at the State Mining Bureau in San Francisco and the deputies will reside in the various oil fields. Operators are required to file all records of work done on wells and other pertinent information. The records are to be considercd as confidential unless released by the operator furnishing them. The Supervisor is empowered to order repair work done on wells and if it is not done he can place agents on the ground to do the work. The cost of the repair work becomes a lien upon the property. Abuse of power by the Supervisor is prevented by making his orders subject to review and reversal by an arbitration board appointed by operators.

The law is rather lengthy and explicit, but no rigid construction can be expected to solve such varied problems as exist in our various oil fields. It is believed that operators generally will coopperate with the officials in the endeavor to make the law fit economic and physical conditions.

The underlying purpose of the framers of the law was to establish a technical department that would gather all the facts and present conclusions to those having charge of drilling operations. In other words, it is hoped that the department will fill the place of a consulting engineer. The need of such a position has been recognized by some operators in their own private organization, while others have not realized its valuc or have been unable to bear its expense. It is therefore evident that the first work of the State Mining Bureau must be educative. Every man engaged in the work must primarily be able to touch the chord of human interest and present the technical facts to his audience, the operators, in such a fashion that they can see the subject as clearly as he does. Technical workers have frequently complained that their work is not given 
proper recognition by the public, and in many cases this has been due to the fact that no effort was made to grasp the thread of public thought on that special subject and turn it into the proper channels. The legislation here considered presents one of the best opportunities for those administering it to demonstrate whether or not technical men are able to take hold of a large problem and present it in intelligible form to men not technically educated but thoroughly skilled in drilling deep and difficult wells.

Not alone to the oil operators, but also to the public which is interested in conservation of the oil, as well as all other natural resources, is the Bureau under obligation to solve the problem outlined in this paper. California drillers have already proved their ability to cope successfully with the most severe physical conditions and will undoubtedly be found willing to assist the engineer who now has an opportunity to demonstrate his usefulness.

\section{Discussion}

M. E. Lombardi, Berkeley, Cal.--Mr. Bell, I would ask you to state before the meeting what you said to me the other day, about the final recovery of oil from oil sands that have become inundated with water.

A. F. L. BeiL, San Francisco, Cal.-In stating my opinion, I give it with certain qualifications. In the Kern field, and possibly in some others, I think we will eventually get all the oil out, whether the water comes in or not, since it is peculiarly constructed, being in the form of a partial dome. In 1909, while I was field manager of the Associated Oil 'Co., I installed some large air compressors to handle the water. At that time the oil had migrated to the higher and more shallow portions of the field, because the water had inundated the deeper sections. The result was that the shallow districts within the center of the dome were in many cases producing as much or more oil per woll than the deeper wells. And in the inundated sections the water .had slowly spread over large areas, so that nothing but water was pumped from them. Under these conditions, we decided to pump the wet well with air, and installed four 2,000-cu. ft. compressors.

The air was compressed and forced into the wet wells at about $25 \dot{0}$ 'lb. pressure. Shortly the inundated district that had produced almost all water and only about $150 \mathrm{bbl}$. of oil a day increased its production to over $2,000 \mathrm{bbl}$. of oil per day. It was not long before we noticed that the production of the shallow territory was falling off to such an extent that in many cases the wells were abandoned; at the same time the area of the water-inundated district was greatly reduced, showing that when the water pressure was reduced the oil migrated back to the lower depth. 
The wells which at first had had the air jets put into them finally produced so much oil that we had to take the air jets out and return to the use of the beam pump, because it is not commercially feasible to pump an oil of $14^{\circ}$ gravity with air. To handle such oil profitably by air, it must carry with it 50 to 90 per cent. of water.

The results have led me to believe that on monoclines, where there is a gradual rise to a certain point, or in plunging anticlines, even though water gets into oil sands, eventually we get the larger percentage of the oil. However, the man with a small acreage in the deeper sections may find some morning that his oil has gone, another man in some higher portion of the district having gotten it.

I do not use this as an argument against any of the means adopted for the prevention of the inundation of water, since infiltration is always a source of danger. Many of my theories have not always worked out, and this is only a theory of mine.

A. C. Moladghuin, San Francisco, Cal.--Supplementing what Mr. Bell has said, the division ownership of lands makes necessary some solution of the water question. Mr. Bell's theory is undoubtedly correct in some cases. However, if there are some 25 or 30 owners, each would like to get the original amount of oil which underlaid his lands.

A. F. L. BeLL.-My theory is that to get oil out of an inundated district, you must reduce the liquid level so that water and oil flow together to the well; but if the water level cannot be reduced and remains at a high level in the well, then the water is a detriment and will shut off the oil. To get all the oil you must have the water under such control that you can pump more water and oil from the well than is coming to it. The moment more water comes to a well than can be handled, then the oil is shut off.

A. C. MCI MAUGHLIN.-By reason of the higher surface tension of water over oil, the tendency is for the water to migrate to lower pressure areas; where pressures are practically nil, the conditions are as Mr. Bell mentions them, but in cases where there are pressures of 25 or $30 \mathrm{lb}$.; the tendency is to migrate toward the well. This displaces the oil and creates an area of low pressure when a well is dug. So I think it is conceivable that by letting water into oil wells, the oil could never be gotten out.

William A. Wiluiams, San Francisco, Cal.--The Bureau of Mines is charged with the supervision of operations on Indian lands in Oklahoma, and we have had the water menace to contend with on these lands. The Cushing field is perhaps one of the best illustrations of the damage that may be done to a field by not effectively excluding the 
water from the oil and gas sands. On March 1, 1915, the production of the Cushing fiêld was in excess of $300,000 \mathrm{bbl}$. per day; today it is less than $140,000 \mathrm{bbl}$. The excessive decline is due to improper methods of casing wells to shut off the water. The operators did not case off the water uniformly; some cased above a certain sand and some cased below the same sand. As there are several producing sands, both oil and gas, in the Cushing field, the result of this unsystematic casing has been intercommunication between sands, permitting the gas to come into contact with the water-bearing sand, and while the gas pressure was sufficient to overcome the hydrostatic pressure of the water sands, the gas forced the water away from the bore hole. When this gas pressure was not sufficient to overcome the hydrostatic pressure, the water found its way into the oil sands, resulting in an abnormal decline in production and the formation of a considerable percentage of cut oil or emulsion. By the drowning and wasting of gas a considerable loss occurred not only in the value of gas as a fuel, but in the matter of operating costs, for where gas occurs with the oil, this gas, when properly conserved, assists in pumping the wells, thus reducing operating costs.

It. was found impracticable to protect with a string of casing each sand found in the Cushing field and in lieu of the large amount of casing necessary to protect the sand adequately, the Bureau of Mines has recommended sealing with 'mud all oil, gas, water, and barren sands, above the productive sands. This is accomplished by landing a string of casing immediately above the sand to be utilized, sealing with mud all sands behind this casing.

In one of the Kansas fields, where the gas occurred at 1,500 ft. and oil at 2,500 ft., a strong flow of top water was encountered above the gas. sand. Wells were drilled, the water and gas sands mudded off behind a single string of casing; the oil wells were drilled in at a cost $\$ 500$ less than required to complete wells without the use of the mud fluid, notwithstanding that the well had to be drilled for a considerable distance with the fluid in the hole. The saving was accomplished in the reduced amount of casing required, the company drilling separate wells for gas.

A. F. L. BenL.--A law should be enacted requiring that all sands above the oil-producing sand should be cased off.

William A. Williams.- It is necessary that all water sands, in fact all sands, be cased off uniformly. Unless this is done, water will find its way through the sands into the producing sand notwithstanding the fact that water may have been effectively shut off at different casing points in the various wells.

MarK L. Requa, San Francisco, Cal.-I would like to ask Mr. McLaughlin whether he has decided how far he can go in remedying the 
water situation. I believe the conditions in certain parts of the State have gone to such an extent that it is dubious whether they can be remedied.

R. P. McLaughlin.--Many old wells have been drilled with no records to show what was put in them and what the conditions were originally. Many of those old wells we cannot remedy since it might cost more to fix them than the wells are worth.

This would be a mere guess, but out of all the old wells we would be fortunate if we could at present fix up 10 or 15 per cent. However, in say, 90 per cent. of the new wells, we should be able to give the operators advice so that we could entirely avoid the damage. One of the largest fields in the world, the Midway-Sunset, has now only about one well to 30 acres of proved oil land, which gives an idea of the great importance of wells yet to be drilled.

Mark L. REQUa.-I am in entire accord with this work, but are we not, in a measure, shutting the door after the horse has run out of the stable. It is true, so far as new wells are concerned, that it will be possible to do much under the supervision of the State Mining Bureau, and in a large measure to avoid the unsatisfactory conditions which exist at a lot of wolls already drilled, but in many old wells it will be impossible to shut off the water.

I have a case of that kind in the Coalinga field, where we drilled a pioneer well. We did not know the formation at the bottom and drilled into an underlying water sand which was not recognized at the time. The hole was not plugged; the casing collapsed, and we redrilled the well. We do not now know where the old casing is. It is within a reasonable limit of the bottom of that hole, but we are utterly unable to get down over the exact spot, clean the hole, and plug it.

That well is producing water, the old casing allowing the entrance of water from the underlying strata.

William A. Williams.- - The water might be shut off by cleaning out the well and filling up with mud, if the well is to be abandoned. In Illinois they have had trouble with edge water. When edge wells begin to show water, the operators cement up 10 or $15 \mathrm{ft}$. of the bottom of the sand, effectively shutting off the water until the water level rises above the top of the cement. The well is again cemented and so on until all of the oil has been exhausted from the sand, when the sand should be effectively plugged, otherwise water may get in and pass through the upper sands into the producing wells. The method of cementing was simple but effective, consisting of placing the necessary cement in the bottom of the well, forcing the cement back into the sand 
with a pressure equal to a column of water possibly $100 \mathrm{ft}$. above the ground-watcr level.

C. D. KEEN, Shreveport, La.-In Louisiana we have no laws which deal with the shutting off of water from the oil sand. About two years ago the Governor of the State appointed a committee of representative oil men from all parts of the State, and requested them to formulate a set of regulations dealing with the conservation of oil and natural gas.

This committee submitted its report, which passed through the legislature, and is known now as the Conservation Law of the State of Louisiana. I was a member of that committee. The point was brought up, whether it would be necessary to embody in the regulations a section, making it compulsory for the oil operator to shut off the salt water from the oil sand.

After some discussion it was the belief of the meeting that the successful shutting off of the water from the oil-bearing strata is of such vital importance for the oil opcrator that it would not be necessary to make any regulations covering that subject. It is impossible in our part of the country to complete an oil well unless the water from the strata above has been shut off entirely.

It may be interesting to give you a short description of the methods we use to shut off the salt water.

In our wells we set a string of 6 -in. casing at a depth ranging from 2,200 to $2,500 \mathrm{ft}$. After we have drilled the holc down to the point where we wish to set the 6-in. casing, we put the casing into the hole; when it reaches the bottom of the hole we displace the drilling mud inside the 6in. casing by running about $500 \mathrm{ft}$. of plugged 4-in. drill pipe inside it. We then mix our cement, usually 30 sacks of cement and 15 sacks of sand, and pour the cement on the heavy mud in the 6-in. casing. When the cement is poured into the 6 -in. casing we follow it up with a wooden plug about $3 \mathrm{ft}$. long and $51 / 2 \mathrm{in}$. in diameter, provided with rubber. washers on both sides, so as to make a tight fit in the casing. After the plug is driven into the pipe, the swivel is screwed on and the string of pipe is lifted up about 8 in. from the bottom; then the pump is started, and the cement with the plug behind it goes to the bottom of the hole. The pump keeps on running until all the cement is pumped outside the bottom of the 6-in. casing, and the plug hits the bottom; this shuts down the pump, and we know that there is no more cement left inside the 6 -in. casing. In order to make sure that the job has been a good one, a steel measuring line is run into the casing to see if the wooden plug is actually down on bottom.

We allow the cement 10 days to harden, and then bail the casing dry. If the cementing has not been successful, we cement the 6-in. 
over again, or set a string of $41 / 2$-in. casing inside the 6 -in., but under no circumstance is the well completed unless the water is shut off satisfactorily. The shutting off of the water in Louisiana has not given much trouble. Until about three years ago we had to rely on gumbo formations to set our casing in, but with the cement process we can set the casing in almost any formation to shut off the water.

I find that the process of cementing in California is somewhat more complicated than ours, which may be explained by the fact that the casings are bigger than ours. It is well known that it is easier to cement a string of 6 -in. casing than a string of 12-in. casing, and I doubt very much if cementing with the single plug would be successful in California.

The committee mentioned above made one regulation which I would like to mention. The surface formations in Texas and Louisiana are soft. and unconsolidated. In the new fields we meet with gas pressures ranging from 450 to $800 \mathrm{lb}$, and the blow-outs we have are sometimes serious. In different places blow-outs took place, forming craters in less than $24 \mathrm{hr}$., in which the derrick and all machinery were buried; one of the most notable instances of that kind was the burning gas well close to Oil City, La., where a crater was formed about $250 \mathrm{ft}$. in diameter and about $50 \mathrm{ft}$. deep. In order to deal successfully with conditions of that kind it was deemed necessary to set in each well a sufficient amount of surface casing, approximately 200 or $300 \mathrm{ft}$., and cement it. When the surface casing is cemented in good shape, and a blow-out is encountered, one has at least one good string to rely on, and the operator is in good shape to kill the blow-out.

In connection with my remark about the use of big casings I would like to ask why such large casings are used in California. A few days ago I visited the Coalinga field, and was told of a well in which was set 2,800 ft. of 12-in. casing. The well was drilled all the way down to the casing point with the rotary system. Would not 8-in. casing have served equally as well?

In our Gulf Coast fields, we get wells in which the casing that shuts off the water is not bigger than 6-in.; and we get some good wells, which make all their production through 6 -in. casing and 41/2-in. liner.

In my opinion, to use a smaller casing in California would save both time and money.

M. E. Lovrardi.-We always try to shut off with $10 \mathrm{in}$., where the collapsing pressure which the pipe will have to bear does not require too heavy a pipe. The object is to finish with $65 / 8$ or $6 \frac{1}{4}$ in. at least, as we find a hole less than $61 / 4$ in. an expensive one from which to produce.

We have to use such small holes, at times. In the western side of the Coalinga field we shut off with $10 \mathrm{in}$. and finish with $81 / 4$. But a condition obtains there (I do not know whether it is edge water coming 
in, or what), that often requires a second shutting off. If it is first shut off with $8 \mathrm{in}$., the second requires $6 \frac{1}{4}$, and next $4 \frac{1}{2}$, and that is not a proper or economical well.

A. C. MoLaughuin.-What percentage of the cementing operation is not successful?

C. D. KEEN.-The majority are successful. I have cemented about 45 wells, and I lost only one cementing job on account of some gas escaping.

Wilimam A. Williams.-What kind of set shoes do you use in Louisiana?

C. D. KEEN.-We use a light shoe, about $2 \mathrm{ft}$. long. Some operators only use reinforced couplings. We do not use heavy shoes at all.

A. F. L. Bell.-Answering Mr. Keen's question, why we use large casing, I might say that in California the conditions are so different from those in the East that he is not the first or only Eastern man who has thought we were extravagant in our work; but there are conditions arising which cannot be understood or appreciated by anyone who has not operated in California fields. Many wells in the East are drilled and placed on the pump for what it costs us to build and equip the derrick and rig on our deep wells. The latter cost us about $\$ 4,000$, and it would be the height of folly to erect them for less. We have formations entirely unknown in the East, consisting of caving ground, and running sands. These are so different from the solid sandstone and limestones in the East that in our experience we have found it was a good plan to use larger pipes and more of them than would be necessary in many other districts.

C. D. KEEN.- - In our company we finish all our wells with the rotary. We drill to the oil sands with thin mud, set the liner in the well, and wash it inside and outside with clear water.

In California, the opinion is that the rotary mud will hurt the well by filling up the voids in the sand. If there is the least gas pressure present to bring the water back out of the formation, it does not hurt the well at all to drill with a rotary.

A. C. McLatghlin.-With rotary drills some wells in California have been drilled in which the oil sand was passed entirely through without its being recognized. The rotary is not satisfactory unless the depth of the oil sand is known before drilling begins.

A. F. L. Ball.- In California our formations do not lie as level as those in the East. In fields that I am familiar with in the East you 
can safely say that the drillers are going to strike the oil sand in a few feet. In California the conditions are entirely different. There are. so many underlying dips and folds that extreme care must be taken in locating the sand in many of the fields. In one case, in the Midway field, we drilled two wells with the rotary at the same time, and in each case we passed through the oil sand without knowing it, and the only thing noticeable while drilling was a few bubbles of gas at one point. In looking for the oil we drilled down into water and at first thought the district was barren, as there was not the slightest indication of oil. Then, after studying the conditions, we thought that possibly the oil sand might be where the little ebullition of gas had been noted. We then cemented off the bottom water in each well; one well came in at 10,000 bbl., and the other at 5,000 bbl. In still another case the rotary showed great quantities of oil in the mud and we expected a gusher, and got a 15-bbl. well. We decided to stop the rotary drilling above the oil sand and finish the well with standard tools. 